\title{
PENGARUH KOMPOSISI KOMPOS LIMBAH KULIT KOPI TERHADAP PERTUMBUHAN BEBERAPA VARIETAS BIBIT KOPI ARABIKA (Coffea arabica L.)
}

\section{Effect of Compost Composition of Coffee Leather Waste on the Growth of Several Coffee Arabica Seed Varieties (Coffea arabica L.)}

\author{
Ridha Tawar Mitha ${ }^{1}$, Erida Nurahmi ${ }^{1}$, Ashabul Anhar ${ }^{*}$ \\ ${ }^{1}$ Jurusan Agroteknologi, Fakultas Pertanian, Universitas Syiah Kuala
}

\begin{abstract}
Abstrak. Kopi merupaakan salaah satu haasil komoiditi perkebun4n yng memilki nilaii ekonoomis yng cukuup tiinggi di aantara taanaman peerkebunan laainnya dan beerperan peenting seebagai sumbeer devisa neegara. Penelitian ini bertujuan untuk mengetahui pertumbuhan beberapa varietas kopi arabika dengan menggunakan kompos limbah kulit kopi. Penelitian ini akan dilaksanakan di Batang Beranun Kecamatan Bandar Kabupaten Bener Meriah dan Laboratorium Fisiologi Tumbuhan Fakultas Pertanian Universitas Syiah Kuala Darussalam Banda Aceh pada April sampai dengan Juni 2018. Penelitian ini menggunakan Rancangan Acak Kelompok (RAK) pola faktorial 3 x 3 yang terdiri dari dua faktor. Adapun faktor yang diteliti adalah beberapa varietas kopi arabika (V) dan faktor kedua dosis pupuk kompos limbah kulit kopi $(\mathrm{K})$. Data yang diperoleh dianalisis dengan menggunakan uji $\mathrm{F}$, dilanjutkan dengan uji BNJ pada taraf 5\%. Hasil penelitian menunjukan bahwa komposisi limbah kulit kopi berpengaruh nyata terhadap pertambahan jumlah daun pada umur 90 HSPT. Terdapat interaksi yang sangat nyata pada pertambahan jumlah daun tanaman kopi arabika.
\end{abstract}

Kata kunci: Varietas ateng janda, ateng keumala, ateng super

\begin{abstract}
Abstrac. Effect of doses of coffee skin waste compost on the growth of several arabica coffee seed varieties. This study aims to determine the effect of doses of coffee skin waste compost and varieties of arabica coffee seedlings on the growth of coffee seedlings. This research was carried out on farmer-owned plantations and plant physiology laboratories majoring in Agrotechnology, Faculty of Agriculture, University of Aceh, Shiite University, Aceh from April to July 2018. This study used a randomized block design of factorial $3 \times 3$ and 3 replications, so there were 27 experimental units and continued with an honest real difference test at the level of 5\% on a significant $\mathrm{f}$ test result. The first factor is the variety with 3 levels, namely: Ateng widows, Ateng super, and Ateng keumala varieties. The second factor is the dose of coffee skin waste compost with 3 levels, namely $25 \%$ and $50 \%$ control. The parameters observed were seedling height, stem base diameter, number of leaves, wet weighted weight and dry weighted weight. The results showed that the treatment of varieties significantly affected wet weight and dry weight at 90 HSPT and did not affect other parameters. Giving several concentrations of local microorganisms significantly affected the number of leaves of the age 8 cacao seedlings of coffee skin waste compost that had no significant effect on all observed parameters. There is no real interaction between the treatment of varieties and doses of coffee skin waste compost.
\end{abstract}

Keywords: Ateng widow's coffee skin waste compost, Ateng super, Ateng keumala.

\section{PENDAHULUAN}

Tanaman kopi merupakan komoditi perkebunan yang memiliki nilai ekonomis yang cukup tinggi di antara tanaman perkebunan lainnya dan berperan penting sebagai sumber devisa negara. Kopi tidak hanya berperan sebagai sumber devisa melainkan juga merupakan sumber penghasilan bagi satu setengah juta jiwa petani kopi di Indonesia (Rubiyo, 2005).

Corresponding author: ashabul anhar@unsyiah.ac.id

Jurnal Ilmiah Mahasiswa Pertanian - AGT, Vol. 4, No. 2, Mei 2019: 141-150 
Provinsi Aceh dan Sumatera Utara merupakan penyumbang lebih dari 50\% produksi kopi Arabika nasional. Akhir-akhir ini pasar kopi yang mempunyai rasa khas (specialty taste) berkembang pesat, khususnya di negara-negara konsumen utama. NCA (2008) melaporkan bahwa konsumsi kopi gourmet (specialty) di Amerika Serikat meningkat dari 14\% pada tahun 2007 menjadi 17\% pada tahun 2008.

Bagi masyarakat Kabupaten Bener Meriah dan Aceh Tengah, kopi identik dengan kehidupan, karena sebagian besar penduduk di wilayah dataran tinggi ini menggantungkan hidupnya dari komoditas kopi. Kabupaten Bener Meriah memiliki kebun kopi dengan luas tanam 39.533 ha dan produktifitas sekitar 0,68 ton/ha/tahun, sedangkan kabupaten Aceh Tengah memiliki kebun kopi dengan luas tanam 48.001 ha dan produksi kopi 0,78 ton/ha/tahun (Dinas Kehutanan dan Perkebunan, 2009).

Menurut Masyarakat Perlindungan Kopi Gayo (MPKG, 2009), produksi kopi Arabika Gayo mencakup lebih dari 90\% dari total produksi kopi di Provinsi Aceh. Komoditas unggulan pertanian di Kabupeten Bener Meriah adalah dari sektor perkebunan, terutaman tanaman kopi. Jumlah produksi tanaman kopi tahun 2016 di Bener Meriah sebanyak 13.980,07 ton dengan luas tanam 42.664,84 ha (Badan Pusat Statistik, 2016).

Menurut Hulupi et al., (2008) Kopi Ateng Janda adalah salah satu jenis kopi yang banyak dibudidayakan karena jenis kopi ateng ini memiliki pohon yang pendek tapi dapat berbuah cepat dan banyak. Kopi Ateng janda mampu menghasilkan buah berkualitas dalam kurun waktu 10 tahun. Biasanya buah kopi tersebut dapat dipanen setiap 2 minggu atau sebulan 2 kali pemanenan. Varietas kopi Ateng Super merupakan keturunan tipe Catimor. Keunggulannya lebih cepat berbuah. Kopi Ateng Super memiliki perawakan semi katai ( $d$ warf) sehingga mudah dibedakan dari varietas Gayo 1 dan Gayo 2 yang lebih kuat. Hal ini diduga berkaitan dengan kebiasaan petani yang jarang melakukan pemupukan terhadap tanaman kopinya. Varietas-varietas berbasis Catimor pada umumnya bersifat rakus hara. Varietas kopi ateng keumala memiliki habitus yang tinggi melebar, seluruh tajuk daun menutupi batang pokok hingga kepermukaan tanah. diameter tajuk $\pm 2,87 \mathrm{~m}$. Percabangan skunder cukup aktif cabang bali dan cabang cacing tidak beraturan tumbuh kesemua arah. Daun tua bewarna hijau, daun muda sebagian besar bewarna coklat beberapa diantaranya bewarna kemerahan. Daun tua berbentuk oval berukuran cukup besar, tebal dan sedikit lebar. 
Salah satu hasil pada proses pengolahan kopi adalah limbah kulit kopi yang dihasilkan pada proses pengolahan limbah kulit kopi. Seiring terjadinya peningkatan produksi kopi, terjadi pula penigkatan limbah kulit kopi. Sebagian masyarakat menaggulangi penumpukan limbah kulit kopi dengan membakarnya. Padahal, seharusnya limbah tersebut dapat menjadi sesuatu yang memiliki nilai tinggi jika di mamfaatkan dengan baik. ( Najiyati et al, 1997).

Pupuk organik adalah pupuk yang tersusun dari materi makhluk hidup, seperti pelapukan sisa-sisa tanaman, hewan, dan manusia. Pupuk organik dapat berbentuk padat atau cair yang digunakan untuk memperbaiki sifat fisik, kimia, dan biologi tanah. Selain harganya murah, pupuk organik mengandung banyak unsur hara. Sumber bahan organik dapat berupa kompos, pupuk hijau, pupuk kandang, limbah ternak, limbah kota (sampah), dan sisa panen salah satunya yaitu limbah kulit kopi (Ayub, 2010).

Keterbatasan informasi dan sosialisasi serta kesadaran masyarakat dalam pengolahan dan pemanfaatan limbah yang dihasilkan oleh kulit kopi, membawa pengaruh pada lingkungan dan apabila tidak ditangani dengan baik dapat menyebabkan masalah baru pada lingkungan, salah satunya yaitu terjadinya penumpukan limbah kulit kopi yang berserakan disekitar pabrik. Pengomposan limbah kulit kopi mesti dilakukan, untuk menghindari pengaruh negatifnya terhadap tanaman akibat rasio $\mathrm{C} / \mathrm{N}$ bahan yang tinggi. Disamping untuk mengurangi volume bahan agar memudahkan dalam aplikasi serta mengurangi pencemaran lingkungan (Najiyati dan Danarti, 1997).

Limbah kulit buah kopi mengandung bahan organik dan unsur hara yang potensial untuk digunakan sebagai media tanam, dikarenakan limbah kulit kopi memiliki kandungan protein yang relatif tinggi sekitar $11 \%$. Hasil analisis proksimat menunjukkan, limbah kulit kopi mengandung 6,67\% protein kasar, dengan serat kasar 18,28\%, lemak 1,0\%, kalsium $0,21 \%$, dan fosfor $0,03 \%$ (Ditjenbun, 2006). Hasil penelitian Irham falahuddin (2016) menyatakan bahwa penambahan limbah kulit kopi 20\% (400g) memberikan pengaruh yang nyata terhadap pertumbuhan tinggi tanaman dan lebar daun bibit kopi. Ketersediaan jumlah limbah kulit kopi di daerah-daerah yang ada di Indonesia, belum termanfaat dengan baik (Londra, 2007).

Kompos kulit biji kopi merupakan salah satu pengganti bahan organik dari pupuk kandang. (Rizkywan, 2014) mengemukakan bahwa dosis kompos kulit kopi berpengaruh nyata terhadap pertumbuhan dan produksi kacang tanah. Menurut penelitian (Adnan, 2014) 
membuktikan bahwa pemberian kompos kulit kopi 300g per lubang tanam jagung manis memberikan pengaruh sangat nyata terhadap tinggi tanaman, jumlah daun, panjang tongkol, berat tongkol dan hasil jagung. Penelitian (Erningtyas, 2016) menunjukan bahwa aplikasi kompos kulit kopi dan pupuk kandang memberikan pengaruh yang sama terhadap budidaya stroberi sehingga kompos kulit kopi dapat digunakan sebagai pengganti pupuk kandang.

\section{BAHAN DAN METODOLOGI PENELITIAN}

Penelitian ini dilaksanakan dilahan perkebunan kopi milik petani Kampung Batang Beranun Kecamatan Bandar Kabupaten Bener Meriah dan Laboratorium Fisiologi Tumbuhan Fakultas Pertanian Universitas Syiahkuala Darusalam Banda Aceh pada 15 Juni sampai dengan 15 September 2018.

Bahan yang digunakan berupa tanah top soil jenis andisol, limbah kulit kopi basah, bibit kopi arabika varietas ateng janda, keumala, super yang berumur 1 bulan dan adapu alat yang digunakan berupa timbangan, jangka sorong, timba, cangkul, meteran, gunting, gembor, kertas label, alat pengangkut tanah (grek), alat tulis, kamera, paranet dan drum.

\section{Pelaksanaan Penelitian}

Pelaksanaan penelitian diawali dengan pembuatan naungan yang bertujuan untuk melindungi tanaman dari sinar matahari bahan yang digunakan adalah paranet dan bambu untuk penyokong. Selanjutnya pembuatan kompos limbah kulit kopi, kompos yang digunakan adalah limbah kulit kopi yng masih basah, kemudian di masukkan kedalam drum $25 \mathrm{~kg}$ dan diberi lubang udara untuk aerasi selama proses pengomposan, kompos limbah kulit kopi siap digunakan setelah di fermentasi selama \pm 1 bulan (Wijayanti, 2014).

Tanah yang digunakan sebagai media tanam untuk bibit kopi adalah lapisan tanah atas top soil yang diambil di sekitar lahan milik petani. Untuk membuat kompos limbah kulit kopi dengan menggunakan timba ukuran $25 \mathrm{~kg}$. Perlakuan $\mathrm{K}_{1}$ (Tanah $75 \%$ dengan kompos $25 \%$ yaitu tanah 3 timba dan kompos 1 timba), perlakuan $\mathrm{K}_{2}$ (tanah $75 \%$ dan kompos $25 \%$ yaitu tanah 3 timba dan kompos 1 timba), perlakuan $\mathrm{K}_{3}$ (tanah 50\% dengan kompos 50\% yaitu 1 timba tanah dan kompos 1 timba). Bibit kopi yang sudah berumur 1 bulan di pindahkan dalam polybag yang telah dipersiapkan dengan cara polybag awal digunting dan dimasukkan kedalam polybag yang 
baru. Bibit yang sudah berumur 4 bulan pada akhir penelitian dilakukan pembongkaran untuk mengamati parameter perumbuhan bibit selama penelitian, adapun parameter yang diamati adalah tinggi tanaman 30, 60 dan 90 HSPT (Hari setelah pindah tanam) pengamatan tiinggi tanaman dilakukan dengan cara mengukur daari paangkal baatang yng sudah ditandai sampai titik tmbuh. Jumlah daun dilakukan pada umur 30, 60 dan 90 HSPT agar dapat diketahui keseluruhan jumlah daun pada akhir penelitian. Diameter pangkal batang di lakukan setelah pembongkaran tanaman yang menggunakan alat ukur (mistar). Berat berangkasan basah dan kering di timbang menggunakan timbangan analitik pada umur 90 HSPT.

\section{HASIL DAN PEMBAHASAN}

\section{Pengaruh varietas terhadap pertumbuhan bibit kopi}

Hasil uji F pada analiss ragam (Lampiran 2 sampai dengan 20) menujukkan bahwa varietas berpengaruh nyata terhadap paramter bobot berangksan basah dan bobot berangkasan kering dan berpengaruh tidak nyata terhadap parameter lainya (tinggi tanaman, jumlah daun, diameter pangkal batang dan panjang akar). Bobot berangkasan basah bibit kopi umur 90 HSPT tertinggi dijumpai pada varietas ateng super $\left(\mathrm{V}_{2}\right)$ menghasilkan bobot tanaman 5,06 g yag berbeda nyata dengan varietas ateng keumala $\left(\mathrm{V}_{3}\right)$ namun berbeda tidak nyata dengan varietas ateng janda (V1). Bobot berangkasan kering bibit kopi umur 90 HSPT tertinggi dijumpai pada varietas ateng super $\left(\mathrm{V}_{2}\right)$ menghasilkan bobot tanaman $1,17 \mathrm{~g}$ yg berbeda nyat dengan varietas ateng keumala $\left(\mathrm{V}_{3}\right)$, namun berbeda tidak nyat dengan varietas ateng janda $\left(\mathrm{V}_{1}\right)$.

\begin{tabular}{lccc|c}
\hline \multirow{2}{*}{ Parameter } & \multicolumn{3}{c|}{ Varietas } & \multirow{2}{*}{ BNJ 0.05} \\
\cline { 2 - 4 } & $\begin{array}{l}\text { Ateng } \\
\text { Janda }\end{array}$ & $\begin{array}{c}\text { Ateng } \\
\text { Super }\end{array}$ & $\begin{array}{c}\text { Ateng } \\
\text { Keumala }\end{array}$ & \\
\hline Tiinggi Biibit 30 HSPT (cm) & 13.82 & 13.96 & 13.52 & - \\
Tiinggi Bibiit 60 HSPT (cm) & 15.15 & 15.55 & 14.85 & - \\
Tiinggi Biibit 90 HSPT (cm) & 17.11 & 17.44 & 16.66 & - \\
Jumlah Daun 30 HSPT (helai) & 7.27 & 7.93 & 7.85 & - \\
Jumlaah Daaun 60 HSPT (helai) & 9.41 & 9.89 & 9.41 & - \\
Jumlaah Daaun 90 HSPT (helai) & 11.33 & 11.74 & 11.44 & - \\
Diameter Pangkal Batang 90 HSPT (mm) & 2.89 & 2.44 & 2.76 & -
\end{tabular}




$\begin{array}{llccr}\text { Panjang Akar 90 HSPT }(\mathrm{cm}) & 14.30 & 14.51 & 13.76 & - \\ \text { Bobot Berangkasan Basah 90 HSPT }(\mathrm{g}) & 3.21 \mathrm{a} & 5.06 \mathrm{a} & 3.09 \mathrm{a} & 2.50 \\ \text { Bobot Berangkasan Kering 90 HSPT }(\mathrm{g}) & 0.74 \mathrm{a} & 1.17 \mathrm{a} & 0.71 \mathrm{a} & 0.57\end{array}$

Keterangan : Angka yang diikuti oleh huruf yang sama berbeda tidak nyata pada taraf 0.05 (Uji BNJ)

Beberapa perlakuan varietas yang telah dilakukan, menunjukkan bahwa pertumbuhan bibit kopi terbaik dijumpai pada varietas ateng super $\left(\mathrm{V}_{2}\right)$. Varietas ateng super memiliki kelebihan yaitu perawakan yang semi katai (pendek) sehingga mudah dibedakan dengan varietas lainnya. Tinggi bibit kopi varietas ateng janda $\left(\mathrm{V}_{1}\right)$ cenderung lebih baik dibandingkan dengan varietas ateng keumala $\left(\mathrm{V}_{3}\right)$ karena pada umur 7 hari setelah tanam terjadi kemarau dilapangan sehingga berpengaruh terhadap pertumbuhan bibit kopi, hal ini sesuai dengan pendapat Danamik (2010), bahwa ada dua faktor yang mempengaruhi pertumbuhan tanaman kopi yaitu faktor faktor lingkungan dan genetis, kemarau juga dapat mempengaruhi iklim dan suhu, faktor yang dapat mempengaruhi proses metabolisme tanaman pada masa pertumbuhan. Menurut Aminuddin et al. (2013) faaktor peenting dalam menentukan tempat dan waktu penanaman tanaman adalah shu udaara, bahkan sebagai faktor penentu pertumbuhan tanaman dan prduksi karena suhu setiap indvidu menunjukkan pertumbuhan dan hasilnya yang beragam sebagai akibat dari pengaruh genetik dan lingkungan. Varietas Ateng Jnda yang relatif lebih dapat beradaptasi dengan kondisi iklim yang kurang baik walaupun varietas tersebut sangat rentan terhadap hama penyakit dibandingkan dengan varietas lainya.

\section{Pengaruh dosis kompos limbah kulit kopi terhadap pertumbuhan bibit kopi}

\begin{tabular}{lccc}
\hline \multirow{2}{*}{ Parameter } & \multicolumn{3}{c}{ Kompos Limbah Kulit Kopi } \\
\cline { 2 - 4 } & Kontrol $\left(\mathrm{K}_{1}\right)$ & $25 \%\left(\mathrm{~K}_{2}\right)$ & $50 \%\left(\mathrm{~K}_{3}\right)$ \\
\hline Tiinggi Biibit 30 HSPT (cm) & 13.72 & 13.45 & 14.15 \\
Tiinggi Biibit 60 HSPT (cm) & 15.00 & 14.70 & 15.85 \\
Tiinggi Biibit 90 HSPT (cm) & 16.43 & 17.00 & 18.00 \\
Jumlaah Daun 30 HSPT (helai) & 7.55 & 7.44 & 8.10 \\
Jumlaah Daun 60 HSPT (helai) & 9.08 & 9.07 & 10.07 \\
\hline
\end{tabular}




\begin{tabular}{lccc}
\hline Jumlaah Daun 90 HSPT (helai) & 10.82 & 11.78 & 12.15 \\
Diameter Pangkal Batang 90 HSPT (mm) & 2.69 & 2.79 & 2.62 \\
Panjang Akar 90 HSPT (cm) & 14.15 & 14.26 & 14.17 \\
Berat Berangkasan Basah 90 HSPT (g) & 3.82 & 3.57 & 3.93 \\
Berat Berangkasan Kering 90 HSPT (g) & 0.88 & 0.83 & 0.90 \\
\hline
\end{tabular}

Hasil uji F pad analisis ragam (Lampiran 2 sampai dengan 22) menunjukkan bahwa pembirian dosis kompos limbah kulit kopi berpengaruh tidak nyata terhadap semua parameter yang diamti. Beberapa perlakuan dosis kompos limbah kulit kopi yang telah dilakukan, menunjukkan bahwa pertumbuhan bibit kopi cenderung lebih baik dijumpai pada dosis $50 \%$. Tinggi bibit umur 30, 60 dan 90 HSPT, jumlah daun umur 30, 60 dan 90 HSPT, diameter pangkal batang 90 HSPT, panjang akar 90 HSPT, bobot berangkasan basah dan bobot berangkasan kering 90 HSPT pada perlakuan dosis kompos limbah kulit kopi berbeda tidak nyata akan tapi pertumbuhan bibt kopi cendrung lebih baik pada pemberian kompos limbah kulit kopi dosis $50 \%\left(\mathrm{~K}_{3}\right)$.

Pemberian dosis kompos limbah kulit kopi tidak berpengaruh nyata terhadap pertumbuhan bibit kopi arabika hal ini diduga kandungan unsur hara (Nitrogen), P (Pospor), $\mathrm{Ca}$ (Kalsium), dan K (Kalium) kurang tersedia dan tidak mudah terserap sehingga menyebabkan pertumbuhan tanaman jadi terhambat. Hal ini sesuai dengan teori Salisbury (1992) menyatakan bahwa unsur-unsur esensial yang dibutuhkan tanaman dalam jumlah relatif besar diistilahkan dengan unsur-unsur makro. Unsur-unsur makro karbon, hidrogen, dan oksigen tersedia bagi tanaman melalui air dan udara. Sementara itu, kebutuhan akan unsur-unsur makro yang lain seperti nitrogen, fosfor, kalium, kalsium, magnesium dan belerang dipenuhi melalui medium tumbuh (Zulkarnain, 2009).

Berdasarkan penelitian yang telah dilakukan dosis limbah kulit kopi berpengaruh tidak nyata terhadap semua parameter yang diamati diduga karena pada saat pembuatan kompos limbah kulit kopi tidak menambahkan bahan yang lainya seperti (EM4) yang salah satu kegunaannya dapat meningkatkan jumlah produksi tanaman dan juga bisa menjaga kestabilan produk hasil pertanian maupun perkebunan dan dapat memfermentasikan bahan organik tanah dan mempercepat dekomposisi. 
Perbaikan fisik tanah dengan pemberian kompos kulit kopi membuat tanah menjadi gembur dan semakin baik. Meningkatnya bahan organik dan tekstur tanah sangat berpengaruh terhadap keadaan sifat-sifat tanah yang lain seperti struktur tanah, permeabilitas tanah dan porositas. Hal ini dapat membuat media tanam mempunyai cadangan air yang cukup untuk pertumbuhan tanaman sehingga dapat meningkatkan serapan hara dan air (Hardjowigeno, 1995).

Sifat biologi tanah yang diperbaiki dengan adanya pemberian kompos kulit kopi yaitu menambah pasokan energi yang diperlukan mikroorganisme tanah, karena umumnya kompos mengandung asam-asam organik sebagai makanan dari mikroorganisme tersebut. Hal ini akan membuat terjaminnya keberadaan mikroorganisme tanah sehingga dapat mempercepat pelepasan unsur hara yang belum terurai di media tanam. Hal ini sejalan dengan pendapat Buckman dan Brady (1982) populasi mikroorganisme tanah meningkat dengan adanya penambahan bahan organik ke dalam tanah. Adanya unsur hara yang sudah terurai oleh mikroorganisme tanah mengakibatkan tersediannya nutrisi yang siap diserap oleh akar tanaman. Penyerapan nutrisi ini akan mempengaruhi pertumbuhan bibit tanaman kopi menjadi cenderung baik selama di pembibitan.

\section{Interaksi antara varietas dengan komposisi limbah kulit kopi terhadap pertumbuhan bibit kopi arabika.}

Hasil analisis ragam menunjukkan bahwa tidak terdapat interaksi anatara varietas dan kompos limbah kulit kopi terhadap semua parameter pertumbuhan bibit kopi arabika. Hal ini dikarenakan pertumbuhan kopi arabika yang berbeda tidak nyata akibat varietas pada taraf yang berbeda tidak dipengaruhi oleh dosis kompos kulit kopi dan begitu juga dengan perlakuan dosis kompos kulit kopi tidak berpengaruh terhadap varietas. Hal ini terjadi karena kedua faktor tersebut tidak saling mempengaruhi pertumbuhan bibit kopi arabika.

\section{KESIMPULAN DAN SARAN}




\section{Kesimpulan}

1. Hasil penelitian menunjukkan bahwa perlakuan varietas berpengaruh nyata terhadap bobot berangkasan basah dan bobot berangkasan kering. Pertumbuhan bibit kopi arabika terbaik dijumpai pada varietas ateng super.

2. Hasil penelitian menunjukkan bahwa dosis kompos limbah kulit kopi berpengaruh tidak nyata terhadap semua parameter (tinggi tanaman 30, 60 dan 90 HSPT, jumlah daun 30, 60 dan 90 HSPT, diameter pangkal batang 90 HSPT, panjang akar 90 HSPT, bobot berangkasan basah dan bobot berangkasan kering 90 HSPT). Dosis kompos limbah kulit kopi terbaik cenderung ditunjukkan pada komposisi $50 \%$.

3. Tidak terjadi interaksi yang nyata antara perlakuan varietas dengan dosis kompos kulit kopi.

\section{Saran}

1. Berdasarkan hasil penelitian perlu dilakukkan penelitian lebih lanjut terhadap dosis kompos limbah kulit kopi terhadap varietas lain untuk meningkatkan pertumbuhan bibit kopi.

2. Disarankan untuk menggunakan bibit kopi yang berumur 3 atau 4 bulan dan menggunakan varietas terbaik yaitu Varietas Ateng Super.

3. Disarankan untuk menganalisis kandungan hara kompos limbah kulit kopi.

\section{DAFTAR PUSTAKA}

Ayub. 2010. Laju dekomposisi dan kualitas kompos limbah padat kopi: pengaruh aktivator dan bahan baku kompos. Pelita Perkebunan Jakarta. Vol 1. 21 No. 1

Badan Pusat Statistik. 2016. Survei Sosial Ekonomi Nasional Maret 2016. BPS. Aceh.

Buckman H.O. dan M.C. Brady. 1982. The Nature and Properties of Soil. Terjemahan Soegiman. Ilmu Tanah. Bhratara Karya Aksara. Jakarta.

Hardjowigeno, S. 2010. Ilmu Tanah Akademika Presindo. Jakarta. 288 hal.

Hanafiah. 2010. Biologi Tanah. Rajawali Press. Jakarta. 184 hal.

Ishar. 2016. Pembibitan Kopi secara Generatif. Kementrian Pertanian Badan Penelitian dan Pengembangan Pertanian BPTP Aceh.

Jumin, H. B. 2002. Dasar-Dasar Agronomi. PT. RajaGrafindo. Jakarta

Leiwakabessy, F. M. 1988. Kesuburan Tanah. Diktat Kuliah, Jurusan Tanah, Fakultas Pertanian, IPB, Bogor. $83 \mathrm{hlm}$.

Lingga, P. 2003. Petunjuk Penggunaan Pupuk. Penebar Swadaya. Jakarta. 
Lizawati. 2002. Analisis interaksi batang bawah dan batang atas pada okulasi tanaman karet. Tesis. Pasca Sarjana Institut Pertanian Bogor.

Londra. 2007. Potensi pemanfaatan limbah kulit kopi. Jurnal balai pengkajian teknologi pertanian, Vol 28 (5):536-542.

MPKG. 2009. Indikasi Geografis Dataran Tinggi Gayo, Kopi Gayo (Arabika) Versi Rinci, Desember 2009.

Marsono dan P. Sigit. 2001. Pupuk Akar, Jenis dan Aplikasinya. Penebar Swadaya. Jakarta

Najiyati. S. dan Danarti. 1997. Budidaya Kopi dan Pengolahan Pasca Panen. Penebar Swadaya. Jakarta.

Najiyati S. dan Danarti. 2007. Kopi, Budidaya dan Penanganan Pascapanen. Depok (ID): Penebar Swadaya.

Nasaruddin. 2008. Bertahan di Zona Pertanian. Bidang Ilmu-ilmu Pertanian. Aceh Tengah.

Novizan. 2002. Petunjuk Pemupukan yang Efektif. Agromedia Pustaka. Jakarta.

Rahardjo, P. 2013. Kopi Panduan Budidaya dan Pengolahan Kopi Arabika dan Robusta. Penebar Swadaya. Jakarta.

Rubiyo, J. 2005. Kajian Rehabilitasi Tanaman Kopi Robusta menjadi Kopi Arabika dengan Teknik Sambung di Kabupaten Bangli. Balai Pengkajian Teknologi Pertanian Bali.

Rizkywan. 2014. Pengaruh lama pengomposan dan dosis kompos limbah kulit kopi terhadap pertumbuhan dan hasil tanaman kacang tanah (Arachis hypogeal L.). Skripsi. Universitas Syiah Kuala. Banda Aceh. 